\title{
Encapsulation Systems for Delivery of Flavonoids: A Review
}

\author{
Mojtaba Yousefi ${ }^{1 \mathbb{D}}$, Mahdi Shadnoush ${ }^{2 \mathbb{( D}}$, Sara Sohrabvandi ${ }^{3(\mathbb{D}}$, Nasim Khorshidian ${ }^{1, *}{ }^{\mathbb{D}}$, Amir M. \\ Mortazavian 4,*(i)
}

1 Food Safety Research Center (Salt), Semnan University of Medical Sciences, Semnan, Iran; m.youefi@semums.ac.ir (M.Y.); nkhorshidian@semums.ac.ir (N.K.);

2 Department of Clinical Nutrition, Faculty of Nutrition Sciences and Food Technology, National Nutrition and Food Technology Research Institute, Shahid Beheshti University of Medical Sciences, Tehran, Iran; mshadnoush@gmail.com (M.S.);

3 Department of Food Technology Research, Faculty of Nutrition Sciences and Food Technology, National Nutrition and Food Technology Research Institute, Shahid Beheshti University of Medical Sciences, Tehran, Iran; sohrabv@sbmu.ac.ir (S.S.);

4 Food Safety Research Center, Shahid Beheshti University of Medical Sciences, Tehran, Iran; mortazvn@ sbmu.ac.ir (A.M.M.);

* Correspondence: nkhorshidian@ semums.ac.ir (N.K.); mortazvn@sbmu.ac.ir (A.M.M.);

Scopus Author ID 57192107570 (N.K.); 12792054500 (A.M.M)

Received: 21.01.2021; Revised: 22.02.2021; Accepted: 24.02.2021; Published: 2.03.2021

\begin{abstract}
Encapsulation of bioactive compounds s been considered a promising tool for preserving these compounds. Several studies on dietary sources and health benefits of flavonoids, their chemical and stability properties, and encapsulation methods used for delivery of flavonoids were reviewed. Flavonoids comprise the main group of polyphenols widely found in fruits and vegetables responsible for numerous biological activities. They have a flavan nucleus with 15 carbon atoms organized in three rings and are categorized into six subgroups. The main dietary sources of flavonoids are fruits, vegetables, cereals, tea, and some herbs such as Viola odorata Linn. These compounds can prevent diseases such as cardiovascular, cancers, neurodegenerative, diabetes, and inflammatory bowel disease. Despite these beneficial biological activities, flavonoids are not stable against environmental conditions, have low water solubility and low bioavailability after oral administration, which restricts their application. Accordingly, encapsulation has been utilized in order to improve the stability and solubility of flavonoids. Various approaches such as spray drying, molecular complexes, liposomes, nanoparticles, emulsification, and multilamellar vesicles have been applied in the entrapment of flavonoids. Encapsulation can improve the stability of flavonoids as well as solubility, controlled release, and bioavailability.
\end{abstract}

Keywords: flavonoid; encapsulation, stability; Viola odorata L.; health benefits.

(C) 2021 by the authors. This article is an open-access article distributed under the terms and conditions of the Creative Commons Attribution (CC BY) license (https://creativecommons.org/licenses/by/4.0/).

\section{Introduction}

In recent years, the role of diet-derived polyphenolic compounds in preventing diseases has been realized [1] that has motivated the consumption of plant-based foods and the development of functional food products enriched with polyphenols. They include a wide variety of diverse structures, which belong to two main classes: non-flavonoids (especially phenolic acids, stilbenes, and lignans) and flavonoids which are characterized by the basic $\mathrm{C}_{6}$ $\mathrm{C}_{3}-\mathrm{C}_{6}$ skeleton [2]. Flavonoids are a group of polyphenolic compounds derived from benzopyrone and broadly distributed in fruits and vegetables [3]. They are synthesized as secondary metabolites in plants through the shikimic pathway by acetic acid//phenylalanine [4]. Besides 
their functionality as natural pigments, it has been reported that they possess antioxidant $[5,6]$, anticancer [7], anti-inflammatory [8,9], antimicrobial and antiviral [10, 11] characteristics. Despite these health-promoting activities, flavonoids have poor stability against environmental conditions (heat, light and oxidation, $\mathrm{pH}$, etc.), low water solubility, and low bioavailability after oral administration, which restrict their applications and health benefits $[3,12,13]$. In this regard, attempts have been conducted to encapsulate flavonoids to preserve their stability and pharmacological activities and masking unpleasant flavor at high concentrations [14].

Encapsulation is a process for entrapment of active ingredients (solid, liquid, or gas) in a wall material to fabricate capsules with a micrometer to millimeter size [15-17]. To prepare capsules with desired properties, the selection of encapsulating agents and method of encapsulation are of great importance. Encapsulating materials must be noticed as "generally recognized as safe" GRAS, inexpensive without reactivity with the core material [18]. Furthermore, functionality, capsule level, target release, and stability should be considered in the coating agent's designation [19]. The main materials used for encapsulation are based on carbohydrates, proteins, and lipids. Microencapsulation techniques are subdivided into three groups; physical methods (spray drying, lyophilization, supercritical fluid precipitation, and solvent evaporation); physicochemical methods (coacervation, liposomes, and ionic gelation), and chemical methods (interfacial polymerization and molecular inclusion complexation) [15, 16, 20]. Therefore, using suitable wall material and encapsulation methods leads to capsules' production with favorable physicochemical properties and acceptable release in the gastrointestinal tract. Overall, in the present review, information on chemistry and dietary sources of flavonoids, their stability, and various encapsulation and delivery systems used for flavonoids are covered to give a better perspective for potential applications in food and future researches.

\section{Flavonoids in Viola odorata L. and Health Benefits}

Flavonoids are the most common phenolic compounds present in all plant parts such as Viola odorata L. and an integral part of human and animal diets. Till now, more than 9000 flavonoids have been reported that and their daily intake is in the range of $20-500 \mathrm{mg}$, principally from dietary sources including tea, red wine, apples, berries, onions, and tomatoes [4]. The presence of flavonoids in vegetables and fruits depends on the type of crop, climate, plant species, type of processing, and storage [21]. The highest level of flavonoids in the human diet consisted of soy isoflavones (genistein, daidzein, biochanin A), flavonols (quercetin, myricetin, kaempferol), and flavones (luteolin and apigenin) [22]. Figure 1 shows flavonoids subgroups, and Table 1 summarizes sources of flavonoids and their level in some foods. More information on the flavonoid content of various foods is supplied by [23].

Emerging evidence from studies has demonstrated the protective effects of food sources rich in flavonoids against different diseases. Altogether, flavonoids represent a broad spectrum of pharmacological properties, including antioxidative, antiallergic, anti-inflammatory, antidiabetic, hepato- and gastro-protective, antiviral, antibacterial, and anticancer activities [29]. Flavonoids are capable of scavenging free radicals and active oxygen species due to their conjugated ring structures and hydroxyl groups. It has been reported that increasing the number of hydroxyl groups and a decrease in glycosylation increased the antioxidant activity of flavonoids [22]. Various flavonoid classes such as flavonol, flavone, and flavanone or isoflavone are potent inhibitors of cycloxygenase-2 (COX-2) and inflammation [30]. Flavonoids exhibit antidiabetic activity by translating glucose transporter type 4 (GLUT4) 
vesicles to the cell membrane, increasing the number of pancreatic $\beta$ cells and insulin secretion, reducing insulin resistance and oxidative stress [31, 32].

Antibacterial activity of flavonoids arises from inactivation of microbial adhesins, inhibition of enzymes and cytoplasmic membrane function, alteration of the membrane permeability, and weakening of the pathogenicity [33, 34]. It has been reported that there is a relation between the structure and inactivation of enzymes associated with the life cycle of the viruses [33].

Flavonoids are effective in different stages of carcinogenesis, including initiation, promotion, and progression. The mechanisms of action consist of inactivation of carcinogens, cell proliferation inhibition, enhancement of DNA repair processes, and reduction of oxidative stress at the initiation stage.

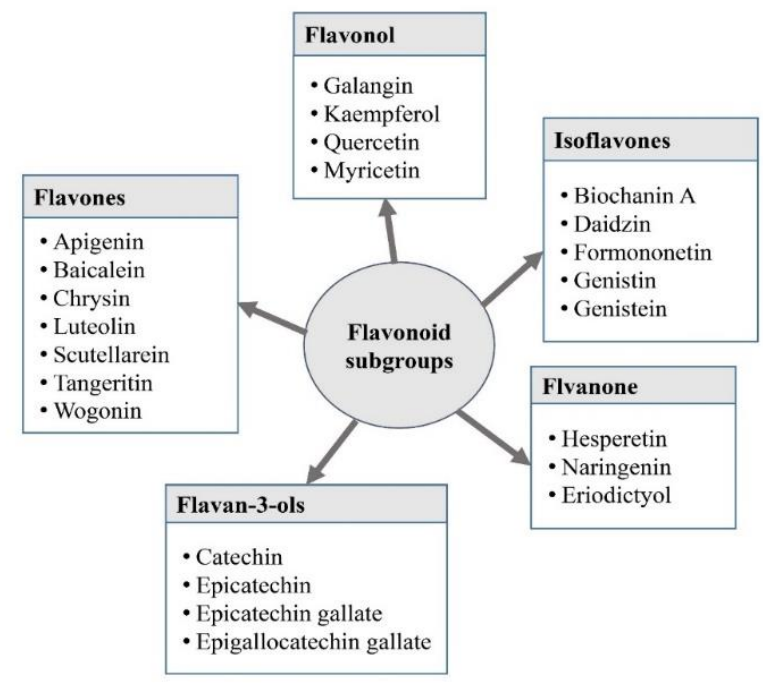

Figure 1. Different subgroups of flavonoids.

Table 1. Sources of flavonoids present in food.

\begin{tabular}{|c|c|c|c|}
\hline Food sample & Type of flavonoid & $\begin{array}{c}\text { Concentration (mg/100 } \mathrm{g} \text { or } \\
100 \mathrm{~mL} \text { sample) }\end{array}$ & Reference \\
\hline $\begin{array}{l}\text { Grapefruit juice } \\
\text { Lemon juice } \\
\text { Orange juice }\end{array}$ & Naringenin & $\begin{array}{l}43.5 \\
0.38 \\
2.13\end{array}$ & [24] \\
\hline $\begin{array}{l}\text { Grapes } \\
\text { Red sorghum } \\
\text { Green olive } \\
\end{array}$ & Luteolin & $\begin{array}{c}<0.1-2.6 \\
<0.2-18.2 \\
0.2-1.2 \\
\end{array}$ & [25] \\
\hline $\begin{array}{l}\text { Lettuce } \\
\text { Chinese cabbage }\end{array}$ & Apigenin & $\begin{array}{l}<0.7-2.7 \\
<0.1-4.5 \\
\end{array}$ & [25] \\
\hline $\begin{array}{l}\text { Basil } \\
\text { Bay }\end{array}$ & Quercetin & $\begin{array}{l}41-86.5 \\
71-250 \\
\end{array}$ & [26] \\
\hline Buckwheat leaves & Rutin & 3417 & [27] \\
\hline Raw cocoa beans & Epicatechin & $270-1235$ & [28] \\
\hline $\begin{array}{l}\text { Oregano } \\
\text { Peppermint }\end{array}$ & Eriodictyol & $\begin{array}{l}85.33 \\
30.92 \\
\end{array}$ & [23] \\
\hline Carob kibbles & Myricetin & 11.67 & [23] \\
\hline $\begin{array}{l}\text { Raw capers } \\
\text { Raw chives } \\
\text { Fresh tarragon }\end{array}$ & kaempferol & $\begin{array}{c}259.19 \\
17.11 \\
11\end{array}$ & [23] \\
\hline
\end{tabular}

In the progression phase, flavonoids may induce apoptosis, inhibit angiogenesis, exhibit antioxidant activity, and induce cytotoxic or cytostatic action against cancer cells [35]. More findings and related studies regarding the exact mechanisms of action and biological activities of flavonoids can be found in the authors' review articles [30, 33, 36-39]. Some biological activities of flavonoids are summarized in Table 2. 
Table 2. Some biological activities of flavonoids

\begin{tabular}{|c|c|c|c|c|}
\hline Biological activity & $\begin{array}{l}\text { Study model and } \\
\text { evaluation method }\end{array}$ & $\begin{array}{l}\text { Concentration } \\
\text { of flavonoids }\end{array}$ & Results & Reference \\
\hline Antioxidant & $\begin{array}{l}\text { DPPH, ABTS scavenging } \\
\text { activity, and ferric reducing } \\
\text { assay }\end{array}$ & $25-1000 \mu \mathrm{M}$ & $\begin{array}{l}\text { Quercetin 7-rhamnoside from Hypericum japonicum } \\
\text { showed antioxidant activity. }\end{array}$ & [40] \\
\hline \multirow[t]{2}{*}{ Anti-inflammatory } & $\begin{array}{l}\text { Release of } \beta \text {-glucuronidase } \\
\text { in rat polymorphonuclear } \\
\text { leukocytes induced by } \\
\text { platelet activating-factor }\end{array}$ & $10 \mu \mathrm{M}$ & $\begin{array}{l}\text { Four flavonoid alkaloids showed anti-inflammatory } \\
\text { activities, with IC50 values against the release of } \beta \text { - } \\
\text { glucuronidase from polymorphonuclear leukocytes } \\
\text { of rats being in the range } 5.16-5.85 \mu \mathrm{M} \text {. }\end{array}$ & [41] \\
\hline & $\begin{array}{l}\text { murine macrophage RAW } \\
264.7 \text { cells stimulated by } \\
\text { LPS and acute lung injury } \\
\text { induced by LPS in mice } \\
\text { were adopted as in vitro and } \\
\text { in vivo models }\end{array}$ & $12.5-100 \mu \mathrm{g} / \mathrm{mL}$ & $\begin{array}{l}\text { Production of NO, PGE2, TNF- } \alpha \text {, IL-6, MCP-1 and } \\
\text { reactive oxygen species (ROS) was significantly } \\
\text { reduced by flavonoids extracted from Artemisia } \\
\text { scoparia Waldst. et kit. Moreover, alveolar } \\
\text { hemorrhage and neutrophil infiltration, as well as } \\
\text { pulmonary histopathologic changes, were } \\
\text { substantially suppressed in lung tissues. }\end{array}$ & {$[42]$} \\
\hline \multirow[t]{2}{*}{ Antidiabetic } & $\begin{array}{lr}\text { Biochemical } & \text { and } \\
\text { histopathological } & \text { studies } \\
\text { carried out in type } & 2 \text { diabetic } \\
\text { Wistar albino rats } & \end{array}$ & 30 and $60 \mathrm{mg} / \mathrm{kg}$ & $\begin{array}{l}\text { Daily oral administration of flavonoid-rich extract of } \\
\text { Synsepalum dulcificum leaf for } 21 \text { days improved } \\
\text { biochemical markers and pathological changes in } \\
\text { diabetic rats. }\end{array}$ & {$[43]$} \\
\hline & 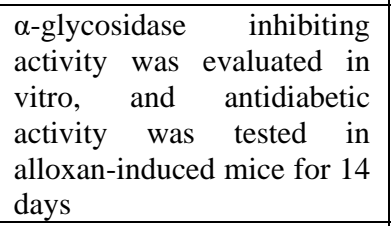 & $\begin{array}{l}10,50, \text { and } 100 \\
\mathrm{mg} / \mathrm{kg} \text { body } \\
\text { weight }\end{array}$ & $\begin{array}{l}\text { Ethyl acetate extract of Binahong Leaves showed } \alpha \text { - } \\
\text { glycosidase inhibition of } 81.23 \mu \mathrm{g} / \mathrm{mL} \text {. The } \\
\text { compound 8-Glucopyranosylapigenin isolated from } \\
\text { Binahong Leaves had enzyme inhibiting activity } \\
\text { with IC } 50 \text { value of } 20.23 \mu \mathrm{g} / \mathrm{mL} \text { and decreased blood } \\
\text { glucose. }\end{array}$ & {$[44]$} \\
\hline Anticancer & $\begin{array}{l}\text { Cellular proliferation and } \\
\text { migration were investigated } \\
\text { in human neuroblastoma } \\
\text { (SH-SY5Y) cells incubated } \\
\text { with isoliquiritigenin }\end{array}$ & $20-100 \mu \mathrm{M}$ & $\begin{array}{l}\text { The results showed that the flavonoid had anti- } \\
\text { proliferative and cytotoxic activity on SH-SY5Y } \\
\text { cells via the ATP loss, induction of cell cycle arrest, } \\
\text { and cell death largely through a necroptotic without } \\
\text { apoptotic activity }\end{array}$ & {$[45]$} \\
\hline Anticancer & 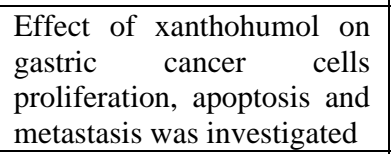 & $1-100 \mu \mathrm{M}$ & $\begin{array}{l}\text { Xanthohumol reduced viability of gastric cancer } \\
\text { cells. Also, it prevented proliferation, apoptosis, and } \\
\text { metastasis in AGC cells. }\end{array}$ & [46] \\
\hline Antimicrobial & $\begin{array}{l}\text { Disc diffusion and broth } \\
\text { dilution assays were used to } \\
\text { investigate the antimicrobial } \\
\text { activity of flavonoids from } \\
\text { Trianthema decandra }\end{array}$ & Not mentioned & $\begin{array}{l}\text { Diameter of the inhibition zone for microorganisms } \\
\text { was in the range of } 20-23 \mathrm{~mm} \text {, and minimal } \\
\text { inhibitory concentration was in the range of } 39.05 \text { - } \\
312.5 \mu \mathrm{g} / \mathrm{mL} \text {. }\end{array}$ & {$[47]$} \\
\hline Antiviral & $\begin{array}{l}\text { Human rhabdomyosarcoma } \\
\text { cells infected with human } \\
\text { enterovirus A71 (HEVA71) }\end{array}$ & $0.005-100 \mu \mathrm{M}$ & $\begin{array}{l}\text { Flavonoids showed antiviral activity at the level of } \\
50 \mu \mathrm{M} \text { and prevented replication of HEVA71. }\end{array}$ & {$[48]$} \\
\hline Cardioprotective & $\begin{array}{l}\text { Cardiotoxicity } r \text { was } \\
\text { evaluated in rats by using } \\
\text { serum biomarkers, lipid } \\
\text { profile, tissue antioxidants, } \\
\text { and histopathological } \\
\text { examinations }\end{array}$ & $100 \mathrm{mg} / \mathrm{kg}$ & $\begin{array}{l}\text { Pretreatment of rats with flavonoids alleviated the } \\
\text { levels of pathological biochemical markers and } \\
\text { increased the levels of endogenous protective } \\
\text { antioxidant proteins in rats }\end{array}$ & [49] \\
\hline
\end{tabular}

\section{Chemical Properties and Stability of Viola odorata L. flavonoids}

, The chemical structure of flavonoids consists of a fifteen-carbon skeleton involving two benzene rings (A and B) linked via a heterocyclic pyrane ring (C) (Figure 2) [33]. They are classified into different groups, including flavanol (e.g., epicatechin, catechin, epicatechin gallate), flavanone (e.g., naringenin, naringin, hesperetin), flavonol (e.g., kaempferol, quercetin, fisetin), flavone (e.g., luteolin, apigenin, chrysin), isoflavone (e.g., daidzein, genistein, daidzin) and anthocyanins [39]. These classes differ in degree of oxidation and substituents of the $\mathrm{C}$ ring, whereas the difference within a class is related to the substitution of the $\mathrm{A}$ and $\mathrm{B}$ rings [50].

Flavonoids are based on 2-phenylchromans (flavonols, flavones, flavanones, flavan-3ols, anthocyanidins, and condensed tannins) and 3-phenylchromans (iso-flavonoids) [37, 51]. 
They can be present as aglycones, glycosides, and methylated derivatives [33]. Flavonoids exhibit various biological activities such as antioxidant and radical scavenging activity, which is originated from a double bond situated between carbons two and three, a hydroxyl group in carbon three, poly-hydroxylation of the aromatic rings A and B, and a carbonyl group located in the carbon four [52]. Flavonoids are crystalline substances with different molecular weights and melting points depending on their structure. Catechins, leucoanthocyanidins, flavanes, isoflavanes, flavanones, flavanonoles are colorless, whereas flavones, flavonoles, chalcones, and aurones are yellow. Flavonoids in glycoside form are soluble in diluted alcohols and hot water and in aglycon form, are soluble in apolar organic solvents, and insoluble in water $[37,53]$.

Preparation and food processing can decrease the level of flavonoids depending on the method used [22]. The effect of food processing and formulation on flavonoid behavior has been reviewed [54]. It has been pointed out that different thermal processes degrade flavonoids depending on the time duration and temperature of the process and flavonoid structure, food matrix, and presence of oxygen [55-57]. On the other hand, more innovative processes such as microwave, infra-red, high-pressure processing have slightly degraded flavonoids [58, 59]. Moreover, mechanical processes such as peeling, trimming, chopping, slicing, crushing and pressing can decrease the level of flavonoids [60,61]. Flavonoids are also damaged by common domestic processes, including boiling, frying, baking, steam-cooking, and microwaving [6264]. Studies regarding the effect of light on flavonoids revealed that these compounds might either increase depending on the type of food (fresh or processed). In fresh fruit and vegetables, light induces stress signals and increases flavonoid synthesis [65-67]. The light wavelength, $\mathrm{pH}$, concentration, and structure of flavonoids affect flavonoids' degradation by light [54].

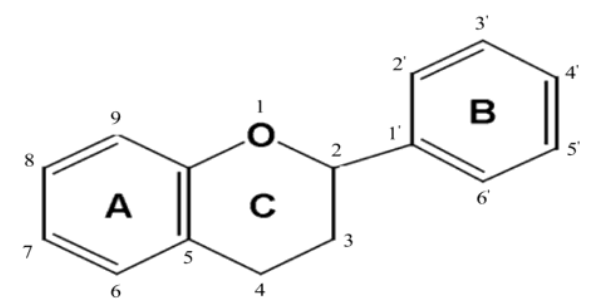

Figure 2. Basic chemical structure of flavonoids.

\section{Encapsulation Systems for Flavonoids}

Although flavonoids possess potential health benefits, their weak stability and insolubility are obstacles to their incorporation into foods. Also, flavonoids degrade in the extreme acidic $\mathrm{pH}$ of gastric juice resulting in low bioavailability and absorption [3]. Therefore, it seems that encapsulation can be an effective approach for the protection of these compounds. Numerous methods and coating substances are used for the encapsulation of bioactive components. The methods are classified into physical (spray drying, fluid bed coating, centrifugal extrusion, processes using the supercritical fluids), chemical (interfacial polycondensation, in situ polymerization, interfacial polymerization, interfacial cross-linking), and physicochemical (spray cooling, hot melt coating, ionic gelation, solvent evaporation extraction, simple or complex coacervation) $[68,69]$. Delivery systems used for flavonoids are presented in the following sections. Table 3 represents some encapsulation approaches applied for flavonoids. 


\subsection{Spray drying.}

Spray drying is a technique in which a fluid feed is atomized, evaporated, and converted to powder. It is widely used in the food industry because of its low production cost. The spraydried powders are stable and resistant to microbiological and oxidative degradation and have low water activity due to low moisture and water activity and higher solubility and quality characteristics (color, flavor, nutrients) [84, 85]. However, the high temperature of the process $\left(150-220^{\circ} \mathrm{C}\right.$ of inlet air and $50-80^{\circ} \mathrm{C}$ of outlet air) has a detrimental effect on sensitive compounds such as vitamins, colors, lycopene, $\beta$-carotene, and polyphenols [84, 85]. Various coating materials, including maltodextrin, gum arabic, chitosan, and soy protein isolate, have been applied in microencapsulation of anthocyanins, quercetin, and catechins [86-88].

$\mathrm{Hu}$ et al. (2018) [12] encapsulated extracted flavonoids from citrus peels and encapsulated them in gum arabic and whey protein concentrate using spray drying. It was shown that microcapsules prepared with a mixture of gum arabic and whey protein concentrate had higher retention efficiency, encapsulation efficiency, and powder yield, and more stability. Interaction of polyphenols and protein was expressed as the probable reason for higher retention of flavonoids encapsulated in gum arabic and whey protein concentration. Naringenin and quercetin were encapsulated by spray drying (inlet temperature of $125^{\circ} \mathrm{C}$ and outlet temperature of $78-80^{\circ} \mathrm{C}$ ) using cellulose acetate phthalate (CAP) and some surfactants (carboxymethylcellulose, sodium dodecylbenzensulfonate, and Tween 85) to enhance dissolution rate. The results indicated that microcapsules prepared by CAP and Tween had high encapsulation efficiency, homogenous dimensional distribution, and spherical shape [3].

In a study performed by Wu et al. (2014) [89], microcapsules from flavonoids extract of Rhodomyrtus tomentosa (Ait.) Hassk. were prepared by spray-drying (inlet temperature of $150^{\circ} \mathrm{C}$ and outlet temperature of $100^{\circ} \mathrm{C}$ ) and response surface methodology with variables (maltodextrin to gum arabic ratio, solid content, glycerol monostearate, and flavonoids extract to coating material ratio. The highest encapsulation efficiency $(91.75 \%)$ was obtained in conditions with maltodextrin to gum arabic ratio of $1: 1.3(\mathrm{w} / \mathrm{w})$, solid content of $27.4 \%$, glycerol monostearate of content at $0.25 \%$, and core: coating ration of 3: 7 . maltodextrin to gum arabic ratio and core to coating ratio was mentioned as the most substantial factors affecting encapsulating efficiency. It was noted that a large number of hydroxyl groups present in flavonoid extract could form hydrogen bonds with gum arabic retaining flavonoids throughout the spray drying. Furthermore, microcapsules' antioxidant activity remained unchanged and higher than citric acid and rutin at the same concentration.

Palma et al. (2012) [90] investigated the release kinetics of flavonoids (quercetin, naringenin, and epicatechin) microparticles prepared with inulin (lipid-insoluble) and Capsul® (lipid-soluble and as channelizing agent) in methyl linoleate. Higher encapsulation efficiency was reported for quercetin and epicatechin $(>60 \%)$ than naringenin $(\sim 40 \%)$ in microcapsules with and without channelizing agent that was ascribed to the higher number of hydroxyl groups in flavonoids structure.

Table 3. Summary of encapsulation methods for flavonoids.

\begin{tabular}{|c|c|c|c|}
\hline Type of flavonoid & Method of encapsulation & Results & Reference \\
\hline Quercetin & $\begin{array}{l}\text { Molecular complex with b- } \\
\text { cyclodextrin }(\beta-C D) \text {, hydroxypropyl- } \\
\beta \text {-cyclodextrin } \quad \text { (HP- } \beta C D) \text { and } \\
\text { sulfobutyl ether } \beta- \\
\text { cyclodextrin }(S B E-\beta C D)\end{array}$ & $\begin{array}{l}\text { Higher scavenging capability than that of } \\
\text { quercetin in water and quercetin-SBE-bCD } \\
\text { complex was the most reactive form }\end{array}$ & [70] \\
\hline
\end{tabular}




\begin{tabular}{|c|c|c|c|}
\hline Type of flavonoid & Method of encapsulation & Results & Reference \\
\hline Quercetin & $\begin{array}{l}\text { Molecular complex with b- } \\
\text { cyclodextrin }(\beta-C D),\end{array}$ & $\begin{array}{l}\text { Higher weight loading with a much lower release } \\
\text { and also improved its solubility, antioxidant } \\
\text { activity, and photostability } \\
\text { properties. }\end{array}$ & [71] \\
\hline Chrysin & $\beta-\mathrm{CD}$ & $\begin{array}{l}\text { Increased the solubility of chrysin as well as its } \\
\text { therapeutic efficacy }\end{array}$ & [72] \\
\hline Rutin & $\mathrm{HP}-\beta-\mathrm{CD}$ & $\begin{array}{l}\text { Enhancement of the oral availability by the } \\
\text { capsulation of rutin by HP- } \beta \text {-CD }\end{array}$ & [73] \\
\hline Naringenin & $\beta$-CD & $\begin{array}{l}\text { Enhanced water solubility and thermal stability of } \\
\text { naringenin }\end{array}$ & [74] \\
\hline Fisetin & sulfobutylether- $\beta$-cyclodextrin & Enhanced the aqueous solubility of fsetin & [75] \\
\hline Apigenin & & $\begin{array}{l}\text { Higher solubility and increased antioxidant } \\
\text { activity }\end{array}$ & {$[76]$} \\
\hline Genistein & $\beta-\mathrm{CD}, \beta-\mathrm{CD}, \mathrm{HP}-\beta-\mathrm{CD}$ and $\mathrm{RM}-\beta-\mathrm{CD}$ & $\begin{array}{l}\text { Higher solubility in the case of HP- } \beta \text {-CD and RM- } \\
\beta \text {-CD } \\
\text { Improvement of the ability to cross the biological } \\
\text { membrane }\end{array}$ & [77] \\
\hline $\begin{array}{l}\text { Hesperetin and } \\
\text { hesperidin }\end{array}$ & $\beta$-CD and HP- $\beta$-CD & $\begin{array}{l}\text { Improvement on the solubility and chemical } \\
\text { stability and better results were achieved in } \\
\text { complex of HP- } \beta \text {-CD and hesperetin }\end{array}$ & [78] \\
\hline Astilbin & $\alpha-, \beta-$, and $\gamma-C D$ & $\begin{array}{l}\text { Solubility of astilbin in } \beta-C D \text { microcapsules } \\
\text { prepared by the freeze-drying method was } \\
\text { enhanced by } 122.1 \text {-fold, and its dissolution profile } \\
\text { was improved }\end{array}$ & [79] \\
\hline Catechin & $\beta-\mathrm{CD}$ & $\begin{array}{l}\text { Higher stability of catechins inclusion complexes } \\
\text { in solid matrix compared to semi-solid and liquid } \\
\text { matrix. Sensory evaluation showed that the } \\
\text { inclusion complex masked the catechin's bitter } \\
\text { taste without affecting the color and overall } \\
\text { acceptance of the product. }\end{array}$ & {$[80]$} \\
\hline Rutin & Chitosan-tripoyphosphate & $\begin{array}{l}\text { High positive charge in optimized nanoparticles. } \\
\text { Retaining rutin in SGF and } 20 \% \text { release in SIF. }\end{array}$ & [81] \\
\hline Hesperetin & $\begin{array}{l}\text { Nanostructured lipid carriers (NLC) } \\
\text { and solid lipid nanoparticles (SLN) }\end{array}$ & $\begin{array}{l}\text { NLC formulations with glycerol monostearate and } \\
0.064 \% \text { hesperetin showed better size, zeta } \\
\text { potential, encapsulation efficiency, stability, and } \\
\text { hesperetin release. }\end{array}$ & [82] \\
\hline Baicalein & $\begin{array}{l}\text { self-microemulsifying drug delivery } \\
\text { systems (SMEDDS) }\end{array}$ & $\begin{array}{l}\text { Baicalein in SMEDDS had a higher release rate } \\
\text { and bioavailability compared to baicalein } \\
\text { suspension. }\end{array}$ & [83] \\
\hline
\end{tabular}

The release rate constant was inversely related with the EE\% and was higher in microcapsules with a channelizing agent that indicated the formation of channels inside the microcapsules resulting in diffusion of flavonoids into methyl linoleate. Furthermore, the release mechanism was independent of flavonoid structure and was only associated with the channelizing agent's presence. The authors pointed out that controlling the release of flavonoids from microcapsules as potential antioxidants can help prevent lipid oxidation in foods.

\subsection{Molecular complexes.}

The physical association of the active ingredient and the coating substance leads to molecular complexes' formation. Cyclodextrins (CD) are interesting molecules used in this context. They are naturally occurring cyclic oligosaccharides consisting of six ( $\alpha$-cyclodextrin), seven ( $\beta$-cyclodextrin), eight ( $\gamma$-cyclodextrin), or more glucopyranose units linked by $(1,4)$ bonds [91, 92]. Cyclodextrins have a truncated cone shape with a hydrophobic internal cavity and hydrophilic external surface, which can enclose hydrophobic molecules inside their internal cavity and improve the dissolution rate, stability, solubility, and bioavailability of bioactive ingredients [87, 93, 94]. Various compounds, including flavors, volatile oils, sweeteners, and polyphenols, have been trapped in cyclodextrins $[69,91]$. 
The majority of studies concerning to encapsulation of flavonoids by cyclodextrins have used $\beta$-cyclodextrin and its derivatives such as hydroxyproyl- $\beta$-cyclodextrin (HP- $\beta$-CD), methyl- $\beta$-cyclodextrin (M- $\beta-C D)$, dimethyl- $\beta$-cyclodextrin (DM- $\beta-C D), \quad$ trimethyl- $\beta$ cyclodextrin (TM- $\beta-\mathrm{CD})$, solphobutylether- $\beta$-cyclodextrin (SBE- $\beta-\mathrm{CD})$, and glucosyl- $\beta$ cyclodextrin (G2- $\beta-\mathrm{CD}$ ) $[94,95]$. The cyclodextrins can interact with flavonoids conducting the B-ring toward the CD's secondary rim or heading the A-ring toward the CD's secondary rim [96].

Yang et al. (2019) [97] investigated the complexation of three flavonoids (taxifolin, quercetin, and morin hydrate) with propanediamine- $\beta$-cyclodextrin (DP- $\beta$-CD). It was stated that the water solubility of taxifolin, quercetin, and morin hydrate was enhanced 70-102 times after resulting in an inclusion complex with DP- $\beta$-CD. Also, the antioxidant activity of DP- $\beta$ $\mathrm{CD} /$ taxifolin complex was better than that of taxifolin. It was declared that hydroxyl groups in taxifolin are close enough to secondary hydroxyl groups of DP- $\beta-C D$ to form intramolecular hydrogen bonds, resulting in an increase of antioxidant activity.

Morin/hydroxypropy- $\beta$-cyclodextrin (1:1 molar ratio) inclusion complex was prepared, and it was demonstrated that dissolution rate, solubility, oral bioavailability, the antihyperalgesic and anti-inflammatory activity of morin was increased [98]. A flavonoid-rich, Allium cepa L. var agrogatum Don extract was encapsulated in $\beta$-CD (1:3 molar ratio), and the results showed that aqueous solubility and the bioavailability of the extract was improved and, according to in vitro skin permeation study, had the potential to be applied for transdermal delivery [99]. In a similar study, methanolic extract of Hypericum perforatum (St John's wort) was encapsulated using $\beta$-CD (1:4 mass ratio). Encapsulation efficiency was reported as 27.5, 30 , and $35 \%$ for catechin, epicatechin, and quercetin, respectively. Moreover, the differential scanning calorimetry test showed the preventive activity of $\beta$-CD against thermal oxidation in the encapsulated extract at temperatures as high as $300^{\circ} \mathrm{C}[100]$.

\subsection{Liposome entrapment.}

Liposomes are non-toxic lipid vesicles composed of phospholipid bilayers organized in water to form an aqueous core surrounded by a lipidic bilayer [87, 101]. This structure can entrap water-soluble, lipid-soluble, and amphiphilic substances [19, 87]. Liposome properties are influenced by lipid composition, surface charge, size, and method of preparation. Therefore, the lipid components' choice defines the rigidity, fluidity, and charge of the lipid bilayer and, consequently, the properties of the liposome. Although liposomes have been studied extensively as suitable carriers for antioxidants, antimicrobials, therapeutic agents, and bioactive compounds [101], high-cost production, low physicochemical stability, drug leakage, and fast release of core substance in the gastrointestinal tract are the major disadvantages [19]. Some approaches have recently been explored to prevail these defects, such as protein coating, chitosan coating, encapsulation using ultrasound, and coating of micronized sucrose and proliposome hydration method [102-105].

In a study by Tao et al. (2014) [106], propolis flavonoids were encapsulated in a liposome that resulted in an increase of immunological activity due to enhancement of the phagocytic function of macrophages and the release of IL-1 $\beta$, IL6, and interferon $\gamma$ and in vivo by activation the cellular and humoral immune response, including inducing higher level concentrations of immunoglobulin (IgG), IL-4, and interferon $\gamma$.

According to the report of Mignet et al. (2012) [107], liposomal encapsulation of fisetin by Phospholipon® ${ }^{\circledR}$ G0 and dioctadecyldimethylammonium chloride-glycin- poly(ethylene 
glycol) 45, yielded liposomes with nanometer scale, high homogeneity, encapsulation efficiency, and stability as well as maintaining cytotoxic and morphological activities on endothelial cells. Similarly, fisetin's liposomal formulation was prepared using 1, 2- dioleoylsn-glycero-3-phosphocholine and dioctadecyldimethylammonium chloridepolyethyleneglycol-2000 with high homogeneity and high encapsulation efficiency, and it was demonstrated that the bioavailability was 47 -fold higher in liposomal form compared to free fisetin. Furthermore, liposomal fisetin prevented the growth of Lewis lung carcinoma tumors for a longer period than free fisetin at the same level [108]. This is in consistent with the results obtained by Goniotaki et al. [109], who reported an increase in growth inhibitory activity of flavonoids entrapped in liposomes.

Quercetin was encapsulated in nanoliposomes using rice bran phospholipids and the thin film sonication method. The quercetin-loaded nanoparticles were spherical with a $157 \mathrm{~nm}$ mean diameter and encapsulation efficiency of $84.92 \%$. Nanoparticles were stable regarding quercetin retention and antioxidant activity stored at 4 and $27^{\circ} \mathrm{C}$ during six months. Release of quercetin from nanoliposomes was limited in SGF (20\% after $4 \mathrm{~h}$ ), while in SIF, an initial release of $60 \%$ after $2 \mathrm{~h}$ and sustained release of $70 \%$ until $24 \mathrm{~h}$ was an indication of an efficient delivery and absorption of quercetin in the intestine [110]. Likewise, quercetin was encapsulated in chitosan-coated nanoliposomes by the electrostatic deposition technique. Encapsulation yielded spherical nanoparticles with $71.14 \%$ encapsulation efficiency and enhanced DPPH antioxidant capacity, hydroxyl radical and superoxide anion radical scavenging capacity, and ferric reducing capacity [103].

\subsection{Polymer nanoparticles.}

Polymer nanoparticles can be manufactured using a variety of ingredients such as natural polymers (proteins and polysaccharides), synthetic polymers (polylactide (PLA), poly lactide-co-glycolide (PLGA), poly glutamic acid, poly (vinyl alcohol)), and inorganic materials $[87,111]$. Encapsulation of quercetin via BSA (bovine serum albumin), zein, chitosan-alginate, PLGA nanoparticles, PLA, Poly (caprolactone, PCL), and glycerol diglycidyl ether (GDE) have been reviewed by [87].

Pool et al. [112] utilized PLGA nanoparticles and the solvent displacement method to encapsulate catechin and quercetin. Polymeric nanoparticles with a mean diameter of $400 \mathrm{~nm}$ and encapsulation efficiency of $79 \%$ were produced. In vitro release study revealed that flavonoids release was $\mathrm{pH}$-dependent, and higher liberation was observed at acidic $\mathrm{pH}$ as a consequence of PLGA degradation. Quercetin showed a slower release compared to catechin, which can be attributed to the carboxyl-carbonyl interactions of the polymer and quercetin. Also, an increase in antiradical and chelating properties of flavonoids was reported by incorporating them into nanoparticles. Pectin nanoparticles containing citrus peel extract were prepared by the ionic gelation method. The obtained nanoparticles had an average size of 271.5 $\mathrm{nm}$, and the release profile in simulated gastric fluid demonstrated $73 \%$ and $28.78 \%$ release from the free extract and encapsulated extract, respectively, after $2 \mathrm{~h}$. The releasing rate of flavonoids reached $91.47 \%$ from nanoparticles after $24 \mathrm{~h}$ in the simulated intestinal fluid (SIF). Furthermore, the encapsulated extract showed higher antioxidant activity than free extract according to DPPH and ABTS assays [113]. In another study by [114], whey protein concentrate was utilized to encapsulate mandarin peel extracts through ionic cross-linking. It was declared that extracts were entrapped in nanoparticles via hydrophobic interactions or hydrogen bonds. Encapsulation of extracts decreased the release rate of flavonoids in 
gastrointestinal fluids and improved antioxidant activity in SIF. Fisetin was nano encapsulated using PCL and poly (D, L-lactic-co-glycolic acid)-block-poly (ethylene glycol)-carboxylic acid (PLGA-PEG-COOH). Nanoparticles had a mean diameter of 140-200 nm and EE\% of 70-82\%. Higher content of PCL in particle formulation yielded higher encapsulation efficiency due to the hydrophobic nature of both fisetin and PCL. Results of in vitro release indicated $<15 \%$ in SGF during $2 \mathrm{~h}$ in all formulations, while in SIF, formulation with a higher content of PLGAPEG-COOH showed $70 \%$ release after $7 \mathrm{~h}$ and complete release after $24 \mathrm{~h}$. In nanoparticles prepared by the only PCL, 54\% and $70 \%$ release after $7 \mathrm{~h}$ and $24 \mathrm{~h}$ was observed, respectively [115].

\subsection{Other types of delivery systems.}

Fisetin was encapsulated by osmoporation using Saccharomyces cerevisiae cells, and the effects of concentration, osmotic pressure, and temperature on the encapsulation and internalized fisetin content were studied. The results illustrated that osmoporation significantly increased EE\% and entrapped fisetin [116].

Akhtar et al. (2014) [117] produced microcapsules containing rutin and Hibiscus anthocyanins in multiple emulsions using a spinning disk reactor (SDR). Using this technology, an emulsion premix was transmitted through a rotating disk at a regulated flow-rate and disk rotation speed which provided controllable and low shear conditions for the preparation of secondary emulsions. It was stated that using $2 \mathrm{wt} . \%$ emulsifier polyoxyethylene (20) stearyl ether produced W/O/W emulsion with fine droplets $(13-15 \mathrm{~nm})$ and $\mathrm{EE}$ of $>80 \%$. The utilization of SDR efficiently encapsulated rutin and anthocyanins within multiple emulsions with a high retention and protection degree.

Onion-type multilamellar vesicles (MLVs) were applied in the entrapment of rutin and naringenin. It was announced that the encapsulation efficiency of naringin was low $(<10 \%)$ and was greatly adsorbed on MLV surface (> 60\%), while rutin showed higher efficiency (> $60 \%$ ). No rutin release was observed in the concentrated MLVs phase during 30 days, and 16\% release was detected in MLVs dispersion after 31 days [13].

Quercetin from dry onion peel crude extract was encapsulated in reassembled casein particles, effects of $\mathrm{pH}$, casein levels, and additives such as salts and Cetyl trimethylammonium bromide (CTAB) on EE\% were studied. The highest EE\% (97\%) was achieved by $0.5 \%(\mathrm{w} / \mathrm{v})$ sodium caseinate, $0.1 \mathrm{M}$ of calcium chloride, $0.5 \mathrm{M}$ of dipotassium hydrogen phosphate, 0.1 $\mathrm{mM}$ CTAB and $1 \mathrm{M}$ of sodium citrate at a $\mathrm{pH}$ of 7 [118]. In another study by Horincar et al. (2019) [119], flavonoids were extracted from yellow onion skins and microencapsulated in whey protein isolate and combinations of chitosan, maltodextrin, and pectin. It was observed that a combination of whey protein isolate, maltodextrin, and pectin resulted in higher $\mathrm{EE} \%$ (71\%) compared to whey protein isolate and chitosan combination (59\%). Also, it was emphasized that flavonoids interacted with whey protein isolate through van der Waals and hydrogen bonding. Ban et al. [120] used nanoparticles made up of physiological lipids to protect flavonoids (naringenin, quercetin and hesperidin) from the digestive system's harsh conditions until their absorption into enterocytes, thereby improving their bioaccessibility. 


\section{Considerable Aspects of Flavonoid Encapsulation}

\subsection{Biological fate.}

One of the key characteristics of an encapsulation system is not having an adverse effect on flavonoids' bioavailability. Various factors, including size, morphology, composition, and interfacial properties, can influence flavonoids' bioavailability [121]. These characteristics are changed during transit of particles from mouth to colon due to the presence of mucin, salts, digestive enzymes, buffers, and acids that affect flavonoids release rate and region [122]. Flavonoids are absorbed in the small intestine in the form of aglycons or are metabolized by intestinal microbiota and absorbed in the colon [33]; hence designing a delivery system that allows the release of flavonoid glycosides in the large intestine is indispensable. Starch-based wall materials used for entrapment of flavonoids are degraded in the mouth by the activity of $\alpha$-amylase. Protein-based delivery systems are hydrolyzed in the stomach exposed to acidic $\mathrm{pH}$ and the enzyme pepsin. Lipid-based particles usually release the core substances in the small intestine [123]. Therefore, the physicochemical features of the substances used to develop flavonoid encapsulates and their digestibility in the gastrointestinal tract and the bioactive ingredient's action site are considerable issues that should be notified.

\subsection{Incorporation into food matrices.}

Although numerous studies have been conducted regarding the encapsulation of flavonoids, few of them reported the stability and effect of their addiction to food matrices. By incorporating microcapsules, appearance, rheology, texture, and sensory properties of food may be altered. Some flavonoids are colorless, and some are yellow, and it is important to consider the point that if the emergence of color in the product is required or not. The incorporation of particles with different sizes, refractive index, and concentration causes changes in foods and beverages' appearance. In transparent food products, delivery systems generating small particles $(\mathrm{d}<50 \mathrm{~nm})$ should be applied while particles with diameters $>50$ can be used in products whose clarity is not required [122]. In addition, the microcapsules produced using gelling materials such as gellan, xanthan, or alginate are usually greater than $100 \mu \mathrm{m}$ and do not provide acceptable mouthfeel and texture in the food formulation [124]. Particles obtained by spray drying are below $40 \mu \mathrm{m}$ and generate a desirable mouthfeel in food products [125]. Furthermore, food products possess various $\mathrm{pH}$ and ionic strength and may undergo harsh processing conditions (freezing, heating, mixing, shearing, and dehydration), leading to the disintegration of microcapsules that should be considered in the design and fabrication of delivery systems [122].

\subsection{Safety.}

The safety of materials utilized in the encapsulation process is of paramount importance. In this respect, a very limited number of coatings and excipient materials have been approved for food use. In some encapsulation methods, the residue of non-food grade solvents and detergents may pose health problems [126] that should be considered in selecting the technique for flavonoid encapsulation. Another challenge is the effect of nanoparticles on the body, dependent on factors including size, composition, surface properties, and their ability to cross the biological membranes [127, 128]. It has been speculated that reduced-size particles have a detrimental impact on the biological system. Nanoparticles might increase the 
bioavailability of bioactive substances and induce health risks [121]. There are still unanswered questions regarding the interaction of nanoparticles and the biological system and their potential toxicity. It is not possible to elucidate the safety of nano-scale encapsulation.

\section{Conclusion and Future Perspective}

Flavonoids are important constituents of many fruits and vegetables, which provide various health benefits that can be extracted from these sources and be utilized to develop functional foods. However, they are sensitive to light, heat, and oxygen. Their poor bioavailability after oral administration and degradation under acidic $\mathrm{pH}$ of stomach limit their successful application. In this respect, different encapsulation systems were introduced in this review that can resolve the mentioned shortcomings. Encapsulation can improve the stability of flavonoids as well as solubility, controlled release, and bioavailability. However, each encapsulation method has its advantages and disadvantages that should be considered in selecting the specific system for the special application field. Based on the collected data, the future development of delivery systems for flavonoids should be centralized on applying foodgrade ingredients as coating materials, other encapsulation methods with higher efficiency, and investigation of the application of microcapsules and their effects in food products.

\section{Funding}

This research received no external funding.

\section{Acknowledgments}

The support for this study provided by Shahid Beheshti University of Medical Sciences is gratefully acknowledged.

\section{Conflicts of Interest}

The authors declare no conflict of interest.

\section{References}

1. Croft, K.D. Dietary polyphenols: Antioxidants or not? Arch Biochem Biophys 2016, 595, 120-4, https://doi.org/10.1016/j.abb.2015.11.014.

2. Amiot, M.; Riva, C.; Vinet, A. Effects of dietary polyphenols on metabolic syndrome features in humans: a systematic review. Obes Rev 2016, 17, 573-86, https://doi.org/10.1111/obr.12409.

3. Sansone, F.; Picerno, P.; Mencherini, T.; Villecco, F.; D'ursi, A.; Aquino, R.; Lauro, M. Flavonoid microparticles by spray-drying: Influence of enhancers of the dissolution rate on properties and stability. J Food Eng 2011, 103, 188-96, https://doi.org/10.1016/j.jfoodeng.2010.10.015.

4. Wang, T.-Y.; Li, Q.; Bi, K.-S. Bioactive flavonoids in medicinal plants: Structure, activity and biological fate. Asian J Pharm Sci 2018, 13, 12-23, https://doi.org/10.1016/j.ajps.2017.08.004.

5. Chlopicka, J.; Pasko, P.; Gorinstein, S.; Jedryas, A.; Zagrodzki, P. Total phenolic and total flavonoid content, antioxidant activity and sensory evaluation of pseudocereal breads. LWT-Food Sci Thecnol 2012, 46, 54855, https://doi.org/10.1016/j.lwt.2011.11.009.

6. Ghasemzadeh, A.; Ghasemzadeh, N. Flavonoids and phenolic acids: Role and biochemical activity in plants and human. J Med Plant Res 2011, 5, 6697-703.

7. Madunić, J.; Madunić, I.V.; Gajski, G.; Popić, J.; Garaj-Vrhovac, V. Apigenin: A dietary flavonoid with diverse anticancer properties. Cancer Lett 2018, 413, 11-22, https://doi.org/10.1016/j.canlet.2017.10.041.

8. Lesjak, M.; Beara, I.; Simin, N.; Pintać, D.; Majkić, T.; Bekvalac, K.; Orčić, D.; Mimica-Dukić, N. Antioxidant and anti-inflammatory activities of quercetin and its derivatives. J Funct Foods 2018, 40, 6875, https://doi.org/10.1016/j.jff.2017.10.047.

9. Spagnuolo, C.; Moccia, S.; Russo, G.L. Anti-inflammatory effects of flavonoids in neurodegenerative disorders. Eur J Med Chem 2018, 153, 105-15, https://doi.org/10.1016/j.ejmech.2017.09.001. 
10. Orhan, D.D.; Özçelik, B.; Özgen, S.; Ergun, F. Antibacterial, antifungal, and antiviral activities of some flavonoids. Microbiol Res 2010, 165, 496-504, https://doi.org/10.1016/j.micres.2009.09.002.

11. Seleem, D.; Pardi, V.; Murata, R.M. Review of flavonoids: A diverse group of natural compounds with antiCandida albicans activity in vitro. Arch Oral Biol 2017, 76, 76-83, https://doi.org/10.1016/j.archoralbio.2016.08.030.

12. Hu, Y.; Li, Y.; Zhang, W.; Kou, G.; Zhou, Z. Physical stability and antioxidant activity of citrus flavonoids in arabic gum-stabilized microcapsules: Modulation of whey protein concentrate. Food Hydrocolloids 2018, 77, 588-97, https://doi.org/10.1016/j.foodhyd.2017.10.037.

13. Kerdudo, A.; Dingas, A.; Fernandez, X.; Faure, C. Encapsulation of rutin and naringenin in multilamellar vesicles for optimum antioxidant activity. Food Chem 2014, 159, 12-9, https://doi.org/10.1016/j.foodchem.2014.03.005.

14. McClements, D.J. Design of nano-laminated coatings to control bioavailability of lipophilic food components. J Food Sci 2010, 75, R30-R42, https://doi.org/10.1111/j.1750-3841.2009.01452.x.

15. Ozkan, G.; Franco, P.; De Marco, I.; Xiao, J.; Capanoglu, E. A review of microencapsulation methods for food antioxidants: Principles, advantages, drawbacks and applications. Food Chem 2019, 272, 494-506, https://doi.org/10.1016/j.foodchem.2018.07.205.

16. Ye, Q.; Georges, N.; Selomulya, C. Microencapsulation of active ingredients in functional foods: From research stage to commercial food products. Trends Food Sci Technol 2018, 78, 167-179, https://doi.org/10.1016/j.tifs.2018.05.025.

17. Yousefi, M.; Khorshidian, N.; Mortazavian, A.M.; Khosravi-Darani, K. Preparation optimization and characterization of chitosan-tripolyphosphate microcapsules for the encapsulation of herbal galactagogue extract. Int J Biol Macromol 2019, 140, 920-8, https://doi.org/10.1016/j.ijbiomac.2019.08.122.

18. Khorshidian, N.; Mahboubi, A.; Kalantari, N.; Hosseini, H.; Yousefi, M.; Arab, M.; da Cruz, A.G.; Mortazavian, A.M.; Mahdavi, F.S. Chitosan-coated alginate microcapsules loaded with herbal galactagogue extract: Formulation optimization and characterization. Iranian Journal of Pharmaceutical Research 2019, 18, 1180-95, https://doi.org/10.22037/ijpr.2019.1100776.

19. Shishir, M.R.I.; Xie, L.; Sun, C.; Zheng, X.; Chen, W. Advances in micro and nano-encapsulation of bioactive compounds using biopolymer and lipid-based transporters. Trends Food Sci Technol 2018, 78, 3460, https://doi.org/10.1016/j.tifs.2018.05.018.

20. Arab, M.; Hosseini, S.M.; Nayebzadeh, K.; Khorshidian, N.; Yousefi, M.; Razavi, S.H.; Mortazavian, A.M. Microencapsulation of microbial canthaxanthin with alginate and high methoxyl pectin and evaluation the release properties in neutral and acidic condition. Int $J$ Biol Macromol 2019, 121, 691-8, https://doi.org/10.1016/j.ijbiomac.2018.10.114.

21. Georgiev, V.; Ananga, A.; Tsolova, V. Recent advances and uses of grape flavonoids as nutraceuticals. Nutrients 2014, 6, 391-415, https://doi.org/10.3390/nu6010391.

22. Yao, L.H.; Jiang, Y.; Shi, J.; Tomas-Barberan, F.; Datta, N.; Singanusong, R.; Chen, S. Flavonoids in food and their health benefits. Plant Foods Hum Nutr 2004, 59, 113-22, https://doi.org/10.1007/s11130-0040049-7.

23. Bhagwat, S.; Haytowitz, D.B.; Holden, J.M. USDA database for the flavonoid content of selected foods, Release 3.1. US Department of Agriculture: Beltsville, MD, USA 2014.

24. Den Hartogh, D.J.; Tsiani, E. Antidiabetic properties of naringenin: a citrus fruit polyphenol. Biomolecules 2019, 9, https://doi.org/10.3390/biom9030099.

25. Hostetler, G.L.; Ralston, R.A.; Schwartz, S.J. Flavones: Food sources, bioavailability, metabolism, and bioactivity. Adv Nutr 2017, 8, 423-35, https://doi.org/10.3945/an.116.012948.

26. Alezandro, M.R.; Lui, M.C.Y.; Lajolo, F.M.; Genovese, M.I. Commercial spices and industrial ingredients: evaluation of antioxidant capacity and flavonoids content for functional foods development. Food Sci Technol 2011, 31, 527-33, http://dx.doi.org/10.1590/S0101-20612011000200038.

27. Habtemariam, S. Antioxidant and Rutin Content Analysis of Leaves of the Common Buckwheat (Fagopyrum esculentum Moench) Grown in the United Kingdom: A Case Study. Antioxidants 2019, 8, 160, http://doi.org/10.3390/antiox8060160.

28. Othman, A.; Jalil, A.M.M.; Weng, K.K.; Ismail, A.; Ghani, N.A.; Adenan, I. Epicatechin content and antioxidant capacity of cocoa beans from four different countries. Afr J Biotechnol 2010, 9, 1052-9, https://doi.org/10.5897/AJB09.1219.

29. González-Paramás, A.M.; Ayuda-Durán, B.; Martínez, S.; González-Manzano, S.; Santos-Buelga, C. The mechanisms behind the biological activity of flavonoids. Curr Med Chem 2019, 26, http://doi.org/10.2174/0929867325666180706104829.

30. Panche, A.; Diwan, A.; Chandra, S. Flavonoids: an overview. J Nutr Sci 2016, 5, http://doi.org/10.1017/jns.2016.41.

31. Babu, P.V.A.; Liu, D.; Gilbert, E.R. Recent advances in understanding the antidiabetic actions of dietary flavonoids. J Nutr Biochem 2013, 24, 1777-89, http://doi.org/10.1016/j.jnutbio.2013.06.003.

32. Vinayagam, R.; Xu, B. Antidiabetic properties of dietary flavonoids: a cellular mechanism review. Nutr Metab 2015, 12, https://doi.org/10.1186/s12986-015-0057-7. 
33. Kumar, S.; Pandey, A.K. Chemistry and biological activities of flavonoids: an overview. The Scientific World Journal 2013, 2013, https://doi.org/10.1155/2013/162750.

34. Xie, Y.; Yang, W.; Tang, F.; Chen, X.; Ren, L. Antibacterial activities of flavonoids: structure-activity relationship and mechanism. Curr Med Chem 2015, 22, 132-49, http://doi.org/10.2174/0929867321666140916113443.

35. Vladu, A.; Marin, S.T,.; Neacsu, I.; Truşcă, R.; Kaya, M.; Kaya, D.; Popa, A.M.; Poiană, C.Ă.; Cristescu, I.O.; Orlov, C. Spongious fillers based on collagen-hydroxyapatite-eugenol acetate with therapeutic potential in bone cancer. Farmacia 2020, 68, 313-21. https://doi.org/10.31925/farmacia.2020.2.17.

36. Ahmad, A.; Kaleem, M.; Ahmed, Z.; Shafiq, H. Therapeutic potential of flavonoids and their mechanism of action against microbial and viral infections-A review. Food Res Int 2015, 77, 221-35, https://doi.org/10.1016/j.foodres.2015.06.021.

37. Faggio, C.; Sureda, A.; Morabito, S.; Sanches-Silva, A.; Mocan, A.; Nabavi, S.F.; Nabavi, S.M. Flavonoids and platelet aggregation: a brief review. Eur J Pharmacol 2017, 807, 91-101, https://doi.org/10.1016/j.ejphar.2017.04.009.

38. Tanaka, T.; Takahashi, R. Flavonoids and asthma. Nutrients 2013, 5, 2128-43, https://doi.org/10.3390/nu5062128.

39. Terahara, N. Flavonoids in foods: a review. Natural product communications. Natural Product Communications 2015, 10, https://doi.org/10.1177/1934578X1501000334.

40. Huang, Z.Q.; Chen, P.; Su, W.W.; Wang, Y.G.; Wu, H.; Peng, W.; Li, P.-B. Antioxidant activity and hepatoprotective potential of quercetin 7-rhamnoside in vitro and in vivo. Molecules 2018, 23, https://doi.org/10.3390/molecules23051188.

41. Han, Q.-T.; Ren, Y.; Li, G.-S.; Xiang, K.-L.; Dai, S.-J. Flavonoid alkaloids from Scutellaria moniliorrhiza with anti-inflammatory activities and inhibitory activities against aldose reductase. Phytochemistry 2018, 152, 91-6, https://doi.org/10.1016/j.phytochem.2018.05.001.

42. Wang, X.; Huang, H.; Ma, X.; Wang, L.; Liu, C.; Hou, B.; Yang, S.; Zhang, L.; Du, G. Anti-inflammatory effects and mechanism of the total flavonoids from Artemisia scoparia Waldst. et kit. in vitro and in vivo. Biomed Pharmacother 2018, 104, 390-403, https://doi.org/10.1016/j.biopha.2018.05.054.

43. Obafemi, T.; Akinmoladun, A.; Olaleye, M.; Agboade, S.O.; Onasanya, A.A. Antidiabetic potential of methanolic and flavonoid-rich leaf extracts of Synsepalum dulcificum in type 2 diabetic rats. J Ayurveda Integr Med 2017, 8, 238-46, https://doi.org/10.1016/j.jaim.2017.01.008.

44. Djamil, R.; Winarti, W.; Zaidan, S.; Abdillah, S. Antidiabetic Activity of Flavonoid from Binahong Leaves (Anredera cordifolia) Extract in Alloxan Induced Mice. J Pharmacogn Nat Prod 2017, 3, 1-4, https://doi.org/10.4172/2472-0992.1000139.

45. Escobar, S.J.d.M.; Fong, G.M.; Winnischofer, S.M.; Simone, M.; Munoz, L.; Dennis, J.M.; Rocha, M.E.M.; Witting, P.K. Anti-proliferative and cytotoxic activities of the flavonoid isoliquiritigenin in the human neuroblastoma cell line SH-SY5Y. Chem Biol Interact 2019, 299, 77-87, https://doi.org/10.1016/j.cbi.2018.11.022.

46. Wei, S.; Sun, T.; Du, J.; Zhang, B.; Xiang, D.; Li, W. Xanthohumol, a prenylated flavonoid from Hops, exerts anticancer effects against gastric cancer in vitro. Oncol Rep 2018, 40, 3213-22, https://doi.org/10.3892/or.2018.6723.

47. Geethalakshmi, R.; Sarada, V.D. In vitro and in silico antimicrobial activity of sterol and flavonoid isolated from Trianthema decandra L. Microb Pathog 2018, 121, 77-86, https://doi.org/10.1016/j.micpath.2018.05.018.

48. Min, N.; Leong, P.T.; Lee, R.C.H.; Khuan, J.S.E.; Chu, J.J.H. A flavonoid compound library screen revealed potent antiviral activity of plant-derived flavonoids on human enterovirus A71 replication. Antiviral Res 2018, 150, 60-8, https://doi.org/10.1016/j.antiviral.2017.12.003.

49. Pradeepkumar, B.; Sudheer, A.; Reddy, T.S.; Reddy, K.S.; Narayana, G.; Veerabhadrappa, K. Cardioprotective Activity of Flavonoid Fraction of Gymnema Sylvestre Leaves on Doxorubicin Induced Cardiac Damage. J Young Pharm 2018, 10, 422, https://doi.org/10.5530/jyp.2018.10.93.

50. Farhadi, F.; Khameneh, B.; Iranshahi, M.; Iranshahy, M. Antibacterial activity of flavonoids and their structure-activity relationship: An update review. Phytotherapy Res 2019, 33, 13-40, https://doi.org/10.1002/ptr.6208.

51. Nabavi, S.F.; Russo, G.L.; Daglia, M.; Nabavi, S.M. Role of quercetin as an alternative for obesity treatment: you are what you eat! Food Chem 2015, 179, 305-10, https://doi.org/10.1016/j.foodchem.2015.02.006.

52. Procházková, D.; Boušová, I.; Wilhelmová, N. Antioxidant and prooxidant properties of flavonoids. Fitoterapia 2011, 82, 513-23, https://doi.org/10.1016/j.fitote.2011.01.018.

53. Chebil, L.; Humeau, C.; Anthoni, J.; Dehez, F.; Engasser, J.M.; Ghoul, M. Solubility of flavonoids in organic solvents. J Chem Eng Data 2007, 52,1552-1556. https://doi.org/10.1021/je7001094.

54. Ioannou, I.; Hafsa, I.; Hamdi, S.; Charbonnel, C.; Ghoul, M. Review of the effects of food processing and formulation on flavonol and anthocyanin behaviour. $J$ Food Eng 2012, 111, 208-17, https://doi.org/10.1016/j.jfoodeng.2012.02.006.

55. Ahmed, M.; Eun, J.-B. Flavonoids in fruits and vegetables after thermal and nonthermal processing: a review. Crit Rev Food Sci Nutr 2018, 58, 3159-88, https://doi.org/10.1080/10408398.2017.1353480. 
56. Ananingsih, V.K.; Sharma, A.; Zhou, W. Green tea catechins during food processing and storage: a review on stability and detection. Food Res Int 2013, 50, 469-79, https://doi.org/10.1016/j.foodres.2011.03.004.

57. Patras, A.; Brunton, N.P.; O'Donnell, C.; Tiwari, B. Effect of thermal processing on anthocyanin stability in foods; mechanisms and kinetics of degradation. Trends Food Sci Technol 2010, 21, 3-11, https://doi.org/10.1016/j.tifs.2009.07.004.

58. Abert-Vian, M.; Elmaataoui, M.; Chemat, F. A novel idea in food extraction field: study of vacuum microwave hydrodiffusion technique for by-products extraction. J Food Eng 2011, 105, 351-60, https://doi.org/10.1016/j.jfoodeng.2011.02.045.

59. Srinivas, K.; King, J.; Monrad, J.; Howard, L.; Zhang, D. Pressurized solvent extraction of flavonoids from grape pomace utilizing organic acid additives. Ital J Food Sci 2011, 23, 90,

60. Al-juhaimi, F.; Ghafoor, K.; Özcan, M.M.; Jahurul, M.; Babiker, E.E.; Jinap, S.; Sahena, F.; Sharifudin, M.; Zaidul, I. Effect of various food processing and handling methods on preservation of natural antioxidants in fruits and vegetables. J Food Sci Technol 2018, 55, 3872-80, https://doi.org/10.1007/s13197-018-3370-0.

61. Pap, N.; Pongrácz, E.; Jaakkola, M.; Tolonen, T.; Virtanen, V.; Turkki, A.; Horváth-Hovorka, Z.; Vatai, G.; Keiski, R.L. The effect of pre-treatment on the anthocyanin and flavonol content of black currant juice (Ribes nigrum L.) in concentration by reverse osmosis. $J$ Food Eng 2010, 98, 429-36, https://doi.org/10.1016/j.jfoodeng.2010.01.024.

62. Islek, M.; Nilufer-Erdil, D.; Knuthsen, P. Changes in Flavonoids of Sliced and Fried Yellow Onions (A llium cepa L. var. zittauer) During Storage at Different Atmospheric, Temperature and Light Conditions. J Food Process Pres 2015, 39, 357-68, https://doi.org/10.1111/jfpp.12240.

63. Miao, J.; Wei, K.; Li, X.; Zhao, C.; Chen, X.; Mao, X.; Huang, H.; Gao, W. Effect of boiling and drying process on chemical composition and antioxidant activity of Chaenomeles speciosa. J Food Sci Technol 2017, 54, 2758-68, https://doi.org/10.1007/s13197-017-2712-7.

64. Yang, N.; Qiu, R.; Yang, S.; Zhou, K.; Wang, C.; Ou, S.; Zheng, J. Influences of stir-frying and baking on flavonoid profile, antioxidant property, and hydroxymethylfurfural formation during preparation of blueberry-filled pastries. Food Chem 2019, 287, 167-75, https://doi.org/10.1016/j.foodchem.2019.02.053.

65. Lee, S.U.; Lee, J.H.; Choi, S.H.; Lee, J.S.; Ohnisi-Kameyama, M.; Kozukue, N.; Levin, C.E.; Friedman, M. Flavonoid content in fresh, home-processed, and light-exposed onions and in dehydrated commercial onion products. Journal of Agricultural and Food Chem 2008, 56, 8541-8, https://doi.org/10.1021/jf801009p.

66. Pérez-Gregorio, M.; García-Falcón, M.; Simal-Gándara, J. Flavonoids changes in fresh-cut onions during storage in different packaging systems. Food Chem 2011, 124, 652-8, https://doi.org/10.1016/j.foodchem.2010.06.090.

67. Wang, C.Y.; Chen, C.-T.; Wang, S.Y. Changes of flavonoid content and antioxidant capacity in blueberries after illumination with UV-C. Food Chem 2009, 117, 426-31, https://doi.org/10.1016/j.foodchem.2009.04.037.

68. Fang, Z.; Bhandari, B. Encapsulation of polyphenols-a review. Trends Food Sci Technol 2010, 21, 510-23, https://doi.org/10.1016/j.tifs.2010.08.003.

69. Munin, A.; Edwards-Lévy, F. Encapsulation of natural polyphenolic compounds; a review. Pharmaceutics 2011, 3, 793-829, https://doi.org/10.3390/pharmaceutics3040793.

70. Jullian, C.; Moyano, L.; Yanez, C.; Olea-Azar, C. Complexation of quercetin with three kinds of cyclodextrins: an antioxidant study. Spectrochim Acta A Mol Biomol Spectrosc 2007, 67, 230-4, https://doi.org/10.1016/j.saa.2006.07.006.

71. Aytac, Z.; Kusku, S.I.; Durgun, E.; Uyar, T. Quercetin/ $\beta$-cyclodextrin inclusion complex embedded nanofibres: Slow release and high solubility. Food Chem 2016, 197, 864-71, https://doi.org/10.1016/j.foodchem.2015.11.051.

72. Zhu, Z.-Y.; Luo, Y.; Liu, Y.; Wang, X.-T.; Liu, F.; Guo, M.-Z.; Wang, Z.; Liu, A.-J.; Zhang, Y.-M. Inclusion of chrysin in $\beta$-cyclodextrin and its biological activities. J Drug Deliv Sci Technol 2016, 31, 176-86, https://doi.org/10.1016/j.jddst.2016.01.002.

73. Miyake, K.; Arima, H.; Hirayama, F.; Yamamoto, M.; Horikawa, T.; Sumiyoshi, H.; Noda, S.; Uekama, K. Improvement of solubility and oral bioavailability of rutin by complexation with 2-hydroxypropyl- $\beta$ cyclodextrin. Pharm Dev Technol 2000, 5, 399-407, https://doi.org/10.1081/PDT-100100556.

74. Yang, L. J.; Ma, S. X.; Zhou, S.Y.; Chen, W.; Yuan, M.W.; Yin, Y.Q.; Yang, X.-D. Preparation and characterization of inclusion complexes of naringenin with $\beta$-cyclodextrin or its derivative. Carbohydr Polym 2013, 98, 861-9, https://doi.org/10.1016/j.carbpol.2013.07.010.

75. Mohtar, N.; Taylor, K.M.; Sheikh, K.; Somavarapu, S. Design and development of dry powder sulfobutylether- $\beta$-cyclodextrin complex for pulmonary delivery of fisetin. Eur J Pharm Biopharm 2017, 113, 1-10, https://doi.org/10.1016/j.ejpb.2016.11.036.

76. Pápay, Z.E.; Sebestyén, Z.; Ludányi, K.; Kállai, N.; Balogh, E.; Kósa, A.; Somavarapu, S.; Böddi, B.; Antal, I. Comparative evaluation of the effect of cyclodextrins and $\mathrm{pH}$ on aqueous solubility of apigenin. J Pharm Biomed Anal 2016, 117, 210-6, https://doi.org/10.1016/j.jpba.2015.08.019.

77. Daruházi, Á.E.; Kiss, T.; Vecsernyés, M.; Szente, L.; Szőke, É.; Lemberkovics, É. Investigation of transport of genistein, daidzein and their inclusion complexes prepared with different cyclodextrins on Caco-2 cell line. J Pharm Biomed Anal 2013, 84, 112-6, https://doi.org/10.1016/j.jpba.2013.05.012. 
78. Tommasini, S.; Calabro, M.; Stancanelli, R.; Donato, P.; Costa, C.; Catania, S.; Villari, V.; Ficarra, P.; Ficarra, R. The inclusion complexes of hesperetin and its 7-rhamnoglucoside with (2-hydroxypropyl)- $\beta$ cyclodextrin. J Pharm Biomed Anal 2005, 39, 572-80, https://doi.org/10.1016/j.jpba.2005.05.009.

79. Zhang, Q.F.; Nie, H.C.; Shangguang, X.C.; Yin, Z.P.; Zheng, G.D.; Chen, J.G. Aqueous solubility and stability enhancement of astilbin through complexation with cyclodextrins. J Agric Food Chem 2012, 61, 151-6, https://doi.org/10.1021/jf304398v.

80. Ho, S.; Thoo, Y.Y.; Young, D.J.; Siow, L.F. Stability and recovery of cyclodextrin encapsulated catechin in various food matrices. Food Chem 2019, 275, 594-9, https://doi.org/10.1016/j.foodchem.2018.09.117.

81. Konecsni, K.; Low, N.; Nickerson, M. Chitosan-tripolyphosphate submicron particles as the carrier of entrapped rutin. Food Chem 2012, 134, 1775-9, https://doi.org/10.1016/j.foodchem.2012.03.070.

82. Fathi, M.; Varshosaz, J.; Mohebbi, M.; Shahidi, F. Hesperetin-loaded solid lipid nanoparticles and nanostructure lipid carriers for food fortification: preparation, characterization, and modeling. Food Bioproc Tech 2013, 6, 1464-75, https://doi.org/10.1007/s11947-012-0845-2.

83. Liu, W.; Tian, R.; Hu, W.; Jia, Y.; Jiang, H.; Zhang, J.; Zhang, L. Preparation and evaluation of selfmicroemulsifying drug delivery system of baicalein. Fitoterapia 2012, 83, 1532-9, https://doi.org/10.1016/j.fitote.2012.08.021.

84. Bora, A.F.M.; Ma, S.; Li, X.; Liu, L. Application of microencapsulation for the safe delivery of green tea polyphenols in food systems: Review and recent advances. Food Res Int 2018, 105, 241-9, https://doi.org/10.1016/j.foodres.2017.11.047.

85. Shishir, M.R.I.; Chen, W. Trends of spray drying: A critical review on drying of fruit and vegetable juices. Trends Food Sci Technol 2017, 65, 49-67, https://doi.org/10.1016/j.tifs.2017.05.006.

86. Gadkari, P.V.; Balaraman, M. Catechins: Sources, extraction and encapsulation: A review. Food Bioprod Process 2015, 93, 122-38, https://doi.org/10.1016/j.fbp.2013.12.004.

87. Wang, W.; Sun, C.; Mao, L.; Ma, P.; Liu, F.; Yang, J.; Gao, Y. The biological activities, chemical stability, metabolism and delivery systems of quercetin: A review. Trends Food Sci Technol 2016, 56, 21-38, https://doi.org/10.1016/j.tifs.2016.07.004.

88. Yousuf, B.; Gul, K.; Wani, A.A.; Singh, P. Health benefits of anthocyanins and their encapsulation for potential use in food systems: a review. Crit Rev Food Sci Nutr 2016, 56, 2223-30, https://doi.org/10.1080/10408398.2013.805316.

89. Wu, P.; Deng, Q.; Ma, G.; Li, N.; Yin, Y.; Zhu, B.; Chen, M.; Huang, R. Spray drying of Rhodomyrtus tomentosa (Ait.) Hassk. flavonoids extract: optimization and physicochemical, morphological, and antioxidant properties. Int J Food Sci 2014, 2014, https://doi.org/10.1155/2014/420908.

90. Palma, M.; García, P.; Márquez-Ruiz, G.; Vergara, C.; Robert, P. Release kinetics of flavonoids in methyl linoleate from microparticles designed with inulin and channelizing agent. Food Res Int 2014, 64, 99-105, https://doi.org/10.1016/j.foodres.2014.05.064.

91. Del Valle, E.M. Cyclodextrins and their uses: a review. Process Biochem 2004, 39, 1033-46, https://doi.org/10.1016/S0032-9592(03)00258-9.

92. Marques, H.M.C. A review on cyclodextrin encapsulation of essential oils and volatiles. Flavour Fragr J 2010, 25, 313-26, https://doi.org/10.1002/ffj.2019.

93. Arora, D.; Saneja, A.; Jaglan, S. Cyclodextrin-based delivery systems for dietary pharmaceuticals. Environ Chem Lett 2019, 17, 1263-1270, https://doi.org/10.1007/s10311-019-00878-w.

94. Bilia, A.R.; Isacchi, B.; Righeschi, C.; Guccione, C.; Bergonzi, M.C. Flavonoids loaded in nanocarriers: an opportunity to increase oral bioavailability and bioefficacy. Food and Nutrition Sciences 2014, 5, https://doi.org/10.4236/fns.2014.513132.

95. Pinho, E.; Grootveld, M.; Soares, G.; Henriques, M. Cyclodextrins as encapsulation agents for plant bioactive compounds. Carbohydr Polym 2014, 101, 121-35, https://doi.org/10.1016/j.carbpol.2013.08.078.

96. Kim, H.; Choi, J.; Jung, S. Inclusion complexes of modified cyclodextrins with some flavonols. J Incl Phenom Macrocycl Chem 2009, 64, https://doi.org/10.1007/s10847-009-9534-9.

97. Yang, S.-L.; Zhao, L.-J.; Chi, S.-M.; Du, J.-J.; Ruan, Q.; Xiao, P.-L.; Zhao, Y. Inclusion complexes of flavonoids with propylenediamine modified $\beta$-cyclodextrin: Preparation, characterization and antioxidant. J Mol Struct 2019, 1183, 118-25, https://doi.org/10.1016/j.molstruc.2019.01.046.

98. dos Santos Lima, B.; de Alcântara Campos, C.; da Silva Santos, A.C.R.; Santos, V.C.N.; Trindade, G.d.G.G.; Shanmugam, S.; Pereira, E.W.M.; Marreto, R.N.; Duarte, M.C.; da Silva Almeida, J.R.G. Development of morin/hydroxypropyl- $\beta$-cyclodextrin inclusion complex: Enhancement of bioavailability, antihyperalgesic and anti-inflammatory effects. Food Chemical Toxicol 2019, 126, 15-24, https://doi.org/10.1016/j.fct.2019.01.038.

99. Ding, Z.; Wu, M.; Guo, Q.; Yang, X.; Zhang, B. Encapsulation of a Flavonoid-rich Allium cepa L. var. agrogatum Don Extract in $\beta$-Cyclodextrin for Transdermal Drug Delivery. J Agric Food Chem 2013, 61, 4914-20, https://doi.org/10.1021/jf302325d.

100. Kalogeropoulos, N.; Yannakopoulou, K.; Gioxari, A.; Chiou, A.; Makris, D.P. Polyphenol characterization and encapsulation in $\beta$-cyclodextrin of a flavonoid-rich Hypericum perforatum (St John's wort) extract. $L W T$ Food Sci Technol 2010, 43, 882-9, https://doi.org/10.1016/j.lwt.2010.01.016. 
101. Simão, A.M.S.; Bolean, M.; Cury, T.A.C.; Stabeli, R.G.; Itri, R.; Ciancaglini, P. Liposomal systems as carriers for bioactive compounds. Biophys Rev 2015, 7, 391-7, https://doi.org/10.1007/s12551-015-0180-8.

102. Gómez-Mascaraque, L.G.; Sipoli, C.C.; de La Torre, L.G.; López-Rubio, A. Microencapsulation structures based on protein-coated liposomes obtained through electrospraying for the stabilization and improved bioaccessibility of curcumin. Food Chem 2017, 233, 343-50, https://doi.org/10.1016/j.foodchem.2017.04.133.

103. Hao, J.; Guo, B.; Yu, S.; Zhang, W.; Zhang, D.; Wang, J.; Wang, Y. Encapsulation of the flavonoid quercetin with chitosan-coated nano-liposomes. LWT-Food Sci Technol 2017, 85, 37-44, https://doi.org/10.1016/j.lwt.2017.06.048.

104. Huang, S.-L.; Hor, T.A.; Jin, G.-X. Photodriven single-crystal-to-single-crystal transformation. Coord Chem Rev 2017, 346, 112-22, https://doi.org/10.1016/j.ccr.2016.06.009.

105. Silva, G.S.; Jange, C.G.; Rocha, J.S.; Chaves, M.A.; Pinho, S.C. Characterisation of curcumin-loaded proliposomes produced by coating of micronised sucrose and hydration of phospholipid powders to obtain multilamellar liposomes. Int J Food Sci Technol 2017, 52, 772-80, https://doi.org/10.1111/ijfs.13334.

106. Tao, Y.; Wang, D.; Hu, Y.; Huang, Y.; Yu, Y.; Wang, D. The immunological enhancement activity of propolis flavonoids liposome in vitro and in vivo. Evid Based Complement Alternat Med 2014, 2014, https://doi.org/10.1155/2014/483513.

107. Mignet, N.; Seguin, J.; Romano, M.R.; Brullé, L.; Touil, Y.S.; Scherman, D.; Bessodes, M.; Chabot, G.G. Development of a liposomal formulation of the natural flavonoid fisetin. Int J Pharm 2012, 423, 69-76, https://doi.org/10.1016/j.ijpharm.2011.04.066.

108. Seguin, J.; Brullé, L.; Boyer, R.; Lu, Y.M.; Romano, M.R.; Touil, Y.S.; Scherman, D.; Bessodes, M.; Mignet, N.; Chabot, G.G. Liposomal encapsulation of the natural flavonoid fisetin improves bioavailability and antitumor efficacy. Int J Pharm 2013, 444, 146-54, https://doi.org/10.1016/j.ijpharm.2013.01.050.

109. Goniotaki, M.; Hatziantoniou, S.; Dimas, K.; Wagner, M.; Demetzos, C. Encapsulation of naturally occurring flavonoids into liposomes: physicochemical properties and biological activity against human cancer cell lines. J Pharm Pharmacol 2004, 56, 1217-24, https://doi.org/10.1211/0022357044382.

110. Rodriguez, E.B.; Almeda, R.A.; Vidallon, M.L.P.; Reyes, C.T. Enhanced bioactivity and efficient delivery of quercetin through nanoliposomal encapsulation using rice bran phospholipids. J Sci Food Agric 2019, 99, 1980-9, https://doi.org/10.1002/jsfa.9396.

111. Amoabediny, G.; Haghiralsadat, F.; Naderinezhad, S.; Helder, M.N.; Akhoundi Kharanaghi, E.; Mohammadnejad Arough, J.; Zandieh-Doulabi, B. Overview of preparation methods of polymeric and lipidbased (niosome, solid lipid, liposome) nanoparticles: A comprehensive review. Int J Polym Mater 2018, 67, 383-400, https://doi.org/10.1080/00914037.2017.1332623.

112. Pool, H.; Quintanar, D.; de Dios Figueroa, J.; Mano, C.M.; Bechara, J.E.H.; Godínez, L.A.; Mendoza, S. Antioxidant effects of quercetin and catechin encapsulated into PLGA nanoparticles. $J$ Nanomater 2012, 2012, 86, https://doi.org/10.1155/2012/145380.

113. Hu, Y.; Zhang, W.; Ke, Z.; Li, Y.; Zhou, Z. In vitro release and antioxidant activity of Satsuma mandarin (Citrus reticulata Blanco cv. unshiu) peel flavonoids encapsulated by pectin nanoparticles. Int J Food Sci Technol 2017, 52, 2362-73, https://doi.org/10.1111/ijfs.13520.

114. Hu, Y.; Kou, G.; Chen, Q.; Li, Y.; Zhou, Z. Protection and delivery of mandarin (Citrus reticulata Blanco) peel extracts by encapsulation of whey protein concentrate nanoparticles. LWT-Food Sci Technol 2019, 99, 24-33, https://doi.org/10.1016/j.lwt.2018.09.044.

115. Sechi, M.; Syed, D.N.; Pala, N.; Mariani, A.; Marceddu, S.; Brunetti, A.; Mukhtar, H.; Sanna, V. Nanoencapsulation of dietary flavonoid fisetin: Formulation and in vitro antioxidant and $\alpha$-glucosidase inhibition activities. Mater Sci Eng C 2016, 68, 594-602, https://doi.org/10.1016/j.msec.2016.06.042.

116. de Câmara, A.A., Jr.; Dupont, S.; Beney, L.; Gervais, P.; Rosenthal, A.; Correia, R.T.P.; Pedrini, M.R.S. Fisetin yeast-based bio-capsules via osmoporation: effects of process variables on the encapsulation efficiency and internalized fisetin content. Appl Microbiol Biotechnol 2016, 100, 5547-58, https://doi.org/10.1007/s00253-016-7425-8.

117. Akhtar, M.; Murray, B.S.; Afeisume, E.I.; Khew, S.H. Encapsulation of flavonoid in multiple emulsion using spinning disc reactor technology. Food Hydrocolloids 2014, 34, 62-7, https://doi.org/10.1016/j.foodhyd.2012.12.025.

118. Ghatak, D.; Iyyaswami, R. Selective encapsulation of quercetin from dry onion peel crude extract in reassembled casein particles. Food Bioprod Process 2019, 115, 100-9, https://doi.org/10.1016/j.fbp.2019.03.003.

119. Horincar, G.; Aprodu, I.; Barbu, V.; Râpeanu, G.; Bahrim, G.E.; Stănciuc, N. Interactions of flavonoids from yellow onion skins with whey proteins: Mechanisms of binding and microencapsulation with different combinations of polymers. Spectrochim Acta A Mol Biomol Spectrosc 2019, 215, 158-67, https://doi.org/10.1016/j.saa.2019.02.100.

120. Ban, C.; Park, S.J.; Lim, S.; Choi, S.J.; Choi, Y.J. Improving flavonoid bioaccessibility using an edible oilbased lipid nanoparticle for oral delivery. J Agric Food Chem 2015, 63, 5266-72, https://doi.org/10.1021/acs.jafc.5b01495. 
121. Steiner, B.M.; McClements, D.J.; Davidov-Pardo, G. Encapsulation systems for lutein: A review. Trends Food Sci Technol 2018, https://doi.org/10.1016/j.tifs.2018.10.003.

122. Davidov-Pardo, G.; McClements, D.J. Resveratrol encapsulation: designing delivery systems to overcome solubility, stability and bioavailability issues. Trends Food Sci Technol 2014, 38, 88-103, https://doi.org/10.1016/j.tifs.2014.05.003.

123. Martínez-Ballesta, M.; Gil-Izquierdo, Á.; García-Viguera, C.; Domínguez-Perles, R. Nanoparticles and controlled delivery for bioactive compounds: Outlining challenges for new "Smart-foods" for health. Foods 2018, 7, https://doi.org/10.3390/foods 7050072.

124. Crittenden, R.; Weerakkody, R.; Sanguansri, L.; Augustin, M. Synbiotic microcapsules that enhance microbial viability during nonrefrigerated storage and gastrointestinal transit. Appl Environ Microbiol 2006, 72, 2280-2, https://doi.org/10.1128/AEM.72.3.2280-2282.2006.

125. Duongthingoc, D.; George, P.; Katopo, L.; Gorczyca, E.; Kasapis, S. Effect of whey protein agglomeration on spray dried microcapsules containing Saccharomyces boulardii. Food Chem 2013, 141, 1782-8, https://doi.org/10.1016/j.foodchem.2013.04.093.

126. Bouwmeester, H.; Dekkers, S.; Noordam, M.Y.; Hagens, W.I.; Bulder, A.S.; De Heer, C.; Ten Voorde, S.E.; Wijnhoven, S.W.; Marvin, H.J.; Sips, A.J. Review of health safety aspects of nanotechnologies in food production. Regul Toxicol Pharmacol 2009, 53, 52-62, https://doi.org/10.1016/j.yrtph.2008.10.008.

127. Ezhilarasi, P.; Karthik, P.; Chhanwal, N.; Anandharamakrishnan, C. Nanoencapsulation techniques for food bioactive components: a review. Food Biopross Tech 2013, 6, 628-47, https://doi.org/10.1007/s11947-0120944-0.

128. Vega-Villa, K.R.; Takemoto, J.K.; Yáñez, J.A.; Remsberg, C.M.; Forrest, M.L.; Davies, N.M. Clinical toxicities of nanocarrier systems. Adv Drug Deliv Rev 2008, 60, 929-38, https://doi.org/10.1016/j.addr.2007.11.007. 